\title{
Work in Progress - Attaining and Measuring Global Competency for Engineering Graduates
}

\author{
James Widmann, Linda Vanasupa \\ California Polytechnic State University, San Luis Obispo, jwidmann@calpoly.edu, lvanasup@calpoly.edu
}

\begin{abstract}
Downey et al. laid out a clear path of learning criteria and outcomes for global competence in their 2006 Journal of Engineering Education publication. We build on their work by integrating other disciplinary perspectives to expand upon the questions: "How can global competency be learned?", and "How can we asses it?" In this work-in-progress paper, we propose an expanded framework for global competence and identify the use of Fink's taxonomy of significant learning as a tool to consider how it can be achieved through careful design of classroom learning experiences. Drawing heavily from other models, our framework attempts to articulate the knowledge, skills, attitudes and experiences necessary for engineering students to attain global competency. The effectiveness of Fink's taxonomy of significant learning for the design of learning experiences that promote global competency is being tested through a unique international capstone design experience with a "quasi-control" group and a test group in which Fink's taxonomy will be used to target specific growth toward global competency. The ideas presented are derived from the international business community, cross-cultural research studies and engineering education research results. Assessment techniques and are also discussed in this work in progress.
\end{abstract}

Index Terms - Global Competency, Intercultural Sensitivity, International Communication.

\section{INTRODUCTION}

The need for engineering professionals to work across cultures and disciplines has been recognized by the National Academy of Engineering in their report on the future of Engineering [1] as well as ABET accreditation criteria [2]. Downey et al., in their analysis of the learning criteria and outcomes in this global era, articulate the following [3]:

Learning criterion - Through the course of instruction and interactions, students will acquire the knowledge, ability and predisposition to work effectively with people who define problems differently than they do.

Learning outcomes-

1. Students will demonstrate substantial knowledge of the similarities and differences among engineers and non-engineers from different countries;
2. Students will demonstrate an ability to analyze how people's lives and experiences in other countries may shape or affect what they consider to be at stake in engineering work;

3. Students will display a predisposition to treat coworkers from other countries as people who have both knowledge and value, may be likely to hold different perspectives than they do, and may be likely to bring these different perspectives to bear in processes of problem definition and problem solution.

This is similar to the definition proposed by Hunter [4] after surveying experts from international education and the international business management community: "having an open mind while actively seeking to understand cultural norms and expectations of others, leveraging this gained knowledge to interact, communicate and work effectively outside one's environment [4]." These criteria, along with those of others [5] suggest a framework of knowledge, skills, and attitudes.

\section{ENGINEERING GLOBAL COMPETENCY FRAMEWORK}

We suggest that a working framework for the global competence proposed by Downey et al., consists of:

Knowledge- geographic, geopolitical, world history, current world events and most importantly specific knowledge of cultures starting with in-depth knowledge of one's own.

Skills- communication (language, written and oral), teamwork, the ability to participate socially and in business settings in other cultures, the ability to cope with unfamiliar situations, and the ability to use appropriate technology to effectively communicate over longdistances

Attitudes- openness towards engaging and learning about other cultures.

We further propose that these three learning outcomes can be built into a range of learning experiences through the use of Fink's taxonomy of significant learning [6]. Fink defines six dimensions of learning: foundational knowledge, application, integration, human dimension, caring, and learning how to learn. These dimensions and their definitions are listed in the Table I below [6]. As shown in the table, Fink's six dimensions map neatly in to knowledge, skills, and attitudes framework. This suggests the use of 
Session F1E

Fink's design methods to foster global competence during engineering learning experiences.

TABLE I

FINK TAXONOMY [6] AND GLOBAL COMPETENCY FRAMEWORK

\begin{tabular}{|c|c|c|}
\hline Fink dimension & Definition & Global Competency \\
\hline $\begin{array}{l}\text { Foundational } \\
\text { knowledge }\end{array}$ & $\begin{array}{l}\text { Understanding and remembering } \\
\text { information, concepts }\end{array}$ & KNOWLEDGE \\
\hline Application & $\begin{array}{l}\text { Skills; critical, creating and } \\
\text { practical thinking; managing } \\
\text { projects }\end{array}$ & SKILLS \\
\hline Integration & Connecting ideas, people; & \\
\hline $\begin{array}{l}\text { Human } \\
\text { Dimension }\end{array}$ & Learning about oneself, others & \\
\hline Caring & $\begin{array}{l}\text { Developing new feelings, interests, } \\
\text { values }\end{array}$ & \\
\hline $\begin{array}{l}\text { Learning How } \\
\text { to Learn }\end{array}$ & $\begin{array}{l}\text { Becoming a better student, self- } \\
\text { directing learning, inquiring about } \\
\text { a subject }\end{array}$ & ATTITUDES \\
\hline
\end{tabular}

\section{PEDAGOGICAL APPROACHES FOR GLOBAL COMPETENCY}

At California Polytechnic State University in San Luis Obispo (Cal Poly) there are collaborative projects between Cal Poly students and students at international institutions as part of regular courses or extracurricular clubs such as the student service organization, Engineers Without Borders (EWB). The Mechanical Engineering Department has a very active faculty and student exchange program with the Hochschule München as well as specific engineering exchange programs with Chalmers University in Sweden, Seoul National University of Technology as well as four other international institutions. One particularly interesting program is a capstone design experience where Cal Poly students are teamed with students at the Hochshule to design a solution to an industrially supplied problem. The students remain resident at their home institutions while working on the year-long projects. During this experience the students complete a design process from problem definition through prototype construction and testing. Success of the projects relies on close cooperation and communication between the students who reside on separate continents. During this experience the students must overcome communication and cultural barriers as well as learn to use advanced communication technology to complete their projects. Although all students are encouraged to participate in any of these programs, there are currently no formally stated learning objectives related to global competency. This course serves as the quasi-control group, as there were no interventions to target global competency. One goal of this work is to determine the relative effectiveness of pedagogies for attaining global competence in engineering graduates. The first pedagogy to be evaluated is the global capstone design experience as the quasi-control.

To assess one dimension of students' global competence, we will use the model of intercultural competence proposed by Bennett [7]. The Developmental Model of Intercultural
Sensitivity (DMIS) seeks to explain how people develop intercultural sensitivity. The model incorporates six states beginning at Denial ("the state in which one's own culture is experienced as the only real one.") to the highest state, Integration ("... the state in which one's experience of self is expanded to include the movement in and out of different cultural worldviews."). Moreover an instrument for assessing the intercultural state, the Intercultural Development Inventory (IDI) has been validated as an accurate measure of a person's state with respect to the DMIS. Demetry [8] is using the DMIS to gauge the effectiveness of study abroad programs at Worcester Polytechnic Institute.

\section{Status of Work in Progress}

As of February 2008, students in the globally based Capstone course at Cal Poly have finished the design phase of their projects and are moving into construction. For prototype purposes, one half of each project will be built at each home institution and then integrated at the institution that is nearest the project sponsor. Full assessment of this trial year will occur in June. Assessment will be in the form of attitudinal surveys and inventories of intercultural sensitivity (possibly the IDI) and will be available for the fall conference. An expanded program is planned to include more students and projects for the fall of 2008 that incorporates design elements from Fink's taxonomy of significant learning. Demographic data on student groups will be analyzed against differences in their performance on assessment instruments.

\section{ACKNOWLEDGMENT}

This study is supported in part by the National Science Foundation (EEC-0530760). The views expressed represent those of the authors and do not necessarily reflect the views of the National Science Foundation.

\section{REFERENCES}

[1] National Academy of Engineering, The Engineer of 2020:Visions of Engineering in the New Century, National Academies Press, 2004.

[2] Engineering Accreditation Commission, Criteria for Evaluating Engineering Programs, ABET Inc, 2006.

[3] Downey, G.L. et al., "The Globally Competent Engineer: Working Effectively with People Who Define Problems Differently," Journal of Engineering Education, Vol. 95, 2006, pp. 1-17.

[4] Hunter, B., White, G.P., Godbey, G.C., "What Does it Mean to Be Globally Competent?", Journal of Studies in International Education, Vol. 10, 2006, pp. 267-285.

[5] Green, M.F., Olson, C., Internationalizing the Campus: A User's Guide, American Council on Education, Washington D.C.

[6] Fink, L. D. (2003). Creating Significant Learning Experiences:An Integrated Approach to Designing College Courses: Jossey-Bass.

[7] Hammer, M.R., Bennett, M.J., Wiseman, R. "Measuring Intercultural Sensitivity: The Intercultural Development Inventory," International Journal of Intercultural Relations, Vol. 27, 2003, pp. 421-433

October 22 - 25, 2008, Saratoga Springs, NY $38^{\text {th }}$ ASEE/IEEE Frontiers in Education Conference

F1E-12 
[8] Demetry, C., "Work in Progress - Development of Intercultural Sensitivity from Study Abroad Programs," Proceedings of the $37^{\text {th }}$ ASEE/IEEE Frontiers in Education Conference, October 2007 